\title{
Teachers' Challenges on the Implementation of Classroom-Based Assessment for Oral Proficiency: A Literature Review
}

\author{
Nur Ashikin Norhasim, Maslawati Mohamad* \\ Faculty of Education, Universiti Kebangsaan Malaysia, Bangi, Malaysia \\ Email: shikin.norhasim@gmail.com, *maslawati@ukm.edu.my
}

How to cite this paper: Norhasim, N. A., \& Mohamad, M. (2020). Teachers' Challenges on the Implementation of Classroom-Based Assessment for Oral Proficiency: A Literature Review. Creative Education, 11, 1922-1929.

https://doi.org/10.4236/ce.2020.1110140

Received: August 30, 2020

Accepted: October 13, 2020

Published: October 16, 2020

Copyright $\odot 2020$ by author(s) and Scientific Research Publishing Inc. This work is licensed under the Creative Commons Attribution International License (CC BY 4.0).

http://creativecommons.org/licenses/by/4.0/

\begin{abstract}
Oral proficiency is one of the most fundamental skills yet challenging to acquire. Although numerous initiatives and measures have been taken by the Malaysian education authorities in moving towards the cultivation of learners' authentic English communication competency including the implementation of the new classroom-based language assessment through communicative language teaching, Malaysian students still struggle in obtaining the minimum requirement for speaking skill in the established language proficiency tests. In accordance to that, this paper provides a literature review on 1) the challenges faced by teachers related to classroom-based assessment for oral proficiency and 2) past studies on language assessment literacy among Malaysian ESL teachers. Some of the challenges may due to the dependency on summative and standardised tests, difficulties in assessing oral proficiency, ineffective courses and trainings on formative language assessment and the low level of language assessment literacy on formative language assessment among Malaysian ESL teachers. By understanding the limitations encountered by the Malaysian ESL teachers in assessing oral proficiency, education authorities as well as educators may work together in finding the solution.
\end{abstract}

\section{Keywords}

Classroom-Based Assessment (CBA), Oral Proficiency, Language Assessment Literacy, English as a Second Language (ESL)

\section{Introduction}

An interaction can only happen when both parties understand each other, and one of the ways to made it possible is through oral interaction. As for language 
learners, oral proficiency is used to aid them in organising and linking ideas for learning purposes as well as providing them cognitive development support during socialising process which resulted in good academic and work performances (Hill, 2010). Whereas the ability to communicate eloquently will have a greater advantage in landing a career, this is supported by Paneerselvam \& Mohamad (2019) who stated that oral communication skill is one of the basic knowledge expertise stressed as very essential for new employees. This shows how important it is for individuals to be orally proficient in any language-or in this context, English, which is greatly known as the global language.

The outgrowing concern on English oral competencies' advantages has led to changes in educational system. This statement is evident in the East Asian countries where they have shifted their priority to oral interaction and sociocultural competence over writing skills and traditional grammar-based approaches in order to cultivate learners' authentic English communication skills (Hung, 2018; Butler, 2011; Knapp, Seidlhofer, \& Widdowson, 2009) including Malaysia. One of the major changes made by the Malaysian government is the Malaysian Education Blueprint 2013 - 2025 listed under the Eleven Shifts in Education Transformation (Shift 2) which is to ensure every child is proficient in Bahasa Malaysia and English language and is encouraged to learn an additional language (Ministry of Education Malaysia, 2012). This shift is also in line with the latest language policy, "Upholding Bahasa Melayu, Strengthening English Language" or known in Malay as Memartabatkan Bahasa Malaysia, Memperkukuhkan Bahasa Inggeris (MBMMBI) introduced in 2010 (Le Ha, Kho, \& Chng, 2013).

In order to make sure all children are able to be bilingually proficient and most importantly use English as a language of communication, the framework in the new curriculum known as Common European Framework Reference (CEFR) highlighted the importance of Communicative Language Teaching (CLT) (Aziz, Ab Rashid, \& Zainudin, 2018). According to Nunan (2003), some of the principles of CLT are student-centred learning and contextualised language use. This approach also stresses on learning the language for communication rather than grammatical knowledge (Aziz, Ab Rashid, \& Zainudin, 2018). In order to rationalise this approach in the new curriculum, the learners' oral competencies alongside other skills are attended through classroom-based assessment (CBA) where learners' everyday progress are evaluated and assessed by teachers.

However, despite the multiple initiatives taken by the government to obtain the goal, the oral competencies of Malaysian students were still slightly below the standard. According to the latest International English Language Testing System (IELTS), the world's most prevalent English language proficiency test for higher education and global migration, Malaysia is placed $3^{\text {rd }}$ for 2018's IELTS average test score rankings by country (IELTS, 2018). Despite that, the mean band score for speaking is only 6.79 which is equivalent to Band 6 .

In accordance to the band descriptors, although most Band 6 examinees have no major difficulty in the following aspects: 1) fluency and coherence, 2) lexical 
resource, 3) grammatical range and accuracy and 4) pronunciation; their oral proficiency is still considered under par. This is because the minimum requirement for both undergraduate and postgraduate programmes is Band 7 and above according to Times Higher Education World University Rankings and QS World University Rankings in 2019 for UK universities (IELTS, 2019).

In order to improve the Malaysian ESL learners' oral competencies, it is important to discover what are the possible reasons for the existing situation to occur. The past literatures that have been reviewed stated that the dependency on summative and standardised tests, difficulties in assessing oral proficiency and ineffective courses and trainings on formative language assessment are some of the challenges that teachers need to encounter in order to help enhance ESL learners' oral proficiency. Other past studies stated that the low language assessment literacy among ESL teachers may also be one of the factors that contribute to the oral incompetency among ESL learners. Although most admitted to being somewhat prepared in conducting classroom-based language assessment, all of them agreed that it is crucial for them to be attending more courses on language assessment.

It is hopeful that through these past studies, education authorities have better understanding and exposure of the teachers' perspective towards the challenges they need to go through in order to help improve ESL learners' oral proficiency. In line with this, the literature review will attempt in providing the answers to the following research questions:

- What are the challenges faced by teachers related to classroom-based assessment for oral proficiency?

- What are the levels of language assessment literacy among Malaysian ESL teachers?

\section{Literature Review}

\subsection{Teachers' Challenges on Classroom-Based Assessment for Oral Proficiency}

According to Vongpumivitch (2012), the education system in Asian countries tend to prioritise exam-oriented learning. The dependence on summative and standardised tests is not only applicable in classroom teaching but also for gatekeeping purposes and critical admissions decisions (Hung, 2018). Lan \& Fan (2019) also added that summative assessment has always been something to refer to and have an enormous consequential social effect for high-stakes decision such as grade promotion, acceptance to post-secondary studies and eligibility for scholarships. Due to the great importance held by the traditional assessment, teachers give more attention in preparing the students for the standardised tests and pay less attention in implementing formative assessments. Although it is no doubt that summative assessment has its own benefits, it usually stresses more on reading and writing skills. This resulted in the negligence of speaking and listening skills, contrary to the CLT approach promoted by the new curriculum (Aziz, Ab 
Rashid, \& Zainudin, 2018). This can be seen in Malaysian context where most students are unable to attain reasonable English literacy even after 11 years of schooling (Musa, Lie, \& Azman, 2012; Kaur, 2006; Jalaluddin, Norsimah, \& Kesumawati, 2008) especially on speaking skill.

On top of that, another challenge related to assessing oral proficiency among teachers is due to the difficulty in assessing oral proficiency. According to Cameron (2001) oral or speaking proficiency can be defined as "the active use of language to express meanings so that other people can make sense of them". Although it is easier said than done, Luoma (2004) do stress that being orally proficient in a foreign language (in this context, English) is challenging and exacting. Just as it is difficult to be orally proficient in your non-native language, it is also difficult to assess this skill. Luoma (2004) mentioned that in assessing oral proficiency of students, "the assessors need to make an instantaneous judgement on a range of aspects of what is being said, as it is being said". This means that the assessor needs to grade the individual's oral proficiency according to the given aspect during that short period of time (which is when the speaker is speaking). This process requires a lot of knowledge, skills, experience, training and practice which is difficult even for experienced teachers.

To help the teachers comprehend better of the new CEFR-aligned curriculum, the education authorities provided related trainings and courses. The English Language Standards and Quality Council (ELSQC) comprising of professional bodies and individuals who are experts and practitioners in the field of ELT in Malaysia has decided to use the Cascade Training Model for teacher training in the dissemination of the new CEFR-aligned curriculum (Aziz, Ab Rashid, \& Zainudin, 2018). The Malaysian English Language Education Roadmap explains that the dissemination of CEFR in Malaysia involves the transmission of information from a small initial group known as Master Trainers to successively larger groups which will then become trainers and train another group-the cycle goes on. The disseminated information includes the language learning pedagogy, teaching methodology and language assessment.

Apart from that, another training conducted specifically on CBA is also provided, known as the "Formative Assessment Principles and Practices Training". The aims of the training are to:

1) understand formative assessment principles and practices,

2) recognise that formative assessment is promoted in the CEFR-aligned curriculum for teaching and learning,

3) be able to apply formative assessment in lesson planning,

4) understand how to monitor and interpret formative assessment,

5) understand how to give effective feedback to pupils,

6) be able to discuss challenges to apply formative assessment in practice, and

7) be able to reflect on and discuss future plans.

The prepared courses and trainings on CEFR-aligned curriculum and CBA practices provided by the education authorities are aimed to equip teachers with 
the knowledge, skills and principles required in implementing peer-assessment for classroom practices.

However, it is said to be ineffective due to various problems such as the insufficient preparation on the implementation of CEFR onto the Malaysian education system (Iber, 2014) besides having limited qualified local English teachers who are capable of implementing the new CEFR-aligned curriculum and assessment system. The teachers are only selected to be trainers because they know a little more English than their peers, not because they are specifically trained in Teaching English as a Second Language (TESL) or possessed similar qualifications (Abd Aziz \& Mohd Uri, 2017). The ELSQC also found that many of the schools have reduced the allocated 18 hours of training to 6 hours only due to time constraint, lack of qualified CEFR trainers and other contributing factors (Mohd Uri \& Abd Aziz, 2018). In addition, based on the researcher's experience, it is also found that the trainings on the formative language assessment was only limited to the Head of English Panel for each school and the 5-day Cascading Training on the new CEFR-aligned curriculum where the researcher had been to thrice, did not highlight on language assessment.

\subsection{Language Assessment Literacy among Malaysian ESL Teachers}

According to Stiggins (1991), teachers spent $30 \%$ to $50 \%$ of their teaching and learning period conducting assessment activities. Given the prominence role in today's classroom teaching and learning process, teachers are demanded to possess all aspects of assessment to effectively assess learners' progress and development. Herrera Mosquera \& Macías (2015) argued that individuals who are most vital to receive LAL are in-service language teachers and pre-service language teacher. For the latter, it is considered obligatory to be attending LAL programs or training in order to increase the quality of teachers' professionalism. Brookhart (2011) justified that the training is applicable to education in general, and not solely in language education. Giraldo (2018) also mentioned that there are differences among those who have attended language assessment training and those who not; the former uses assessment to improve teaching and learning, whereas the latter uses it as merely a way to obtain grades. Therefore, studies have been made since then to discover teachers' language assessment literacy.

Limited studies were found on teachers' language assessment literacy in Malaysian context, and most of them were in secondary and tertiary level. One of them is by Ariff et al. (2012) who conducted the study on secondary school ESL teachers in Melaka. Based on the close-ended questionnaire, the result showed that the highest level of perceived LAL among the teachers was on classroom testing and washback, followed by validity and reliability, test design and development and lastly, large scale standardised testing. Although it is found that 44 out of 48 teachers were somewhat prepared in conducting classroom-based lan- 
guage assessment, all teachers acknowledged the importance of having more training courses on language assessment. They also want to learn how to construct better test items such as applying higher order thinking skills (HOTS) in their test items. They also responded in the open-ended questionnaire that new courses on knowledge on language assessment should be provided to teachers twice a year.

In another studies by Suah \& Ong (2012), a majority of Malaysian teachers agreed to having less than satisfactory for their language assessment literacy. This indicated that they only have sound understanding of the assessment but unable to apply it in classroom practices. Sidhu, Kaur, \& Chi (2018) further mentioned that although the teachers were aware that the current formative assessment includes assessment on oral proficiency, they admitted to not being adequately equipped with the knowledge and comprehension of the practices, assessment standards and types of assessment used. Fook \& Sidhu (2006) also found that Malaysian ESL teachers possess limited knowledge in interpreting test scores, conducting item analysis and forming a test bank besides being unfamiliar with terms such as norm-referenced, criterion-referenced, formative and summative assessment.

Based on these past studies, it is found that Malaysian ESL teachers are in dire need of updated knowledge regarding language assessment. Not only it is for the benefits of the teachers' self-development, but it is also required for their professionalism. Most importantly, language assessment literacy is needed for teachers to efficiently monitor the learners' language ongoing progress and development.

\section{Conclusion and Implications}

The existing literatures have identified that the challenges faced by ESL teachers related to classroom-based assessment for oral proficiency are due to the overreliance on summative and standardised tests, difficulties in assessing learners' oral proficiency as well as the ineffective courses and trainings on formative language assessment provided by the Malaysian Ministry of Education. It is also found that the low language assessment literacy among ESL teachers may also have contributed to the ineffective implementation of language assessment in classes.

By understanding the difficulties faced by the Malaysian ESL teachers in assessing the learners' speaking competencies, the education authorities should provide more resourceful trainings and courses on the specified skill so that teachers can get a clearer view on how to assess the learners' speaking competencies effectively. Apart from that, it is also essential for the Malaysian Ministry of Education to better implement the courses of the CEFR-aligned curriculum by electing qualified local English teachers, giving thorough and sufficient preparation on the implementation of CEFR onto the Malaysian education system, providing the formative language assessment courses to all English teachers as well as giving ample time for teachers to fully comprehend the new curriculum 
and formative assessment process. It is also important for educators to carry out more formative assessment on skills that are difficult to assess so that the ESL learners are able to be competent in all skills equally.

\section{Conflicts of Interest}

The authors declare no conflicts of interest regarding the publication of this paper.

\section{References}

Abd Aziz, M. S., \& Mohd Uri, N. F. (2017). CEFR in Malaysia: Current Issues and Challenges in the Implementation of the Framework. In 3rd International Conference on Language Testing and Assessment and the 5th British Council New Directions in Language Assessment Conference. Shanghai: British Council.

Ariff, R., Shahraniza, T., Ismail, I. S., Kasmaruddin, N. I., \& Abdullah, A. H. (2012). Language Assessment Literacy of Malaysian School English Teachers. International Conference on Communication, Language, Education and Social Sciences (pp. 158-164). Malacca: MMU Press.

Aziz, A. H. A. A., Ab Rashid, R., \& Zainudin, W. Z. W. (2018). The Enactment of the Malaysian Common European Framework of Reference (CEFR): National Master Trainer's Reflection. Indonesian Journal of Applied Linguistics, 8, 409-417. https://doi.org/10.17509/ijal.v8i2.13307

Brookhart, S. M. (2011). Educational Assessment Knowledge and Skills for Teachers. Educational Measurement: Issues and Practice, 30, 3-12. https://doi.org/10.1111/j.1745-3992.2010.00195.x

Butler, Y. G. (2011). The Implementation of Communicative and Task-Based Language Teaching in the Asia-Pacific Region. Annual Review of Applied Linguistics, 31, 36. https://doi.org/10.1017/S0267190511000122

Cameron, L. (2001). Teaching Languages to Young Learners. Cambridge: Cambridge University Press. https://doi.org/10.1017/CBO9780511733109

Fook, C. Y., \& Sidhu, G. K. (2006). School-Based Assessment among ESL Teachers in Malaysian Secondary Schools. Journal of the Malaysian Education Deans' Council, 9, $1-18$.

Giraldo, F. (2018). Language Assessment Literacy: Implications for Language Teachers. Profile Issues in Teachers Professional Development, 20, 179-195. https://doi.org/10.15446/profile.v20n1.62089

Herrera Mosquera, L., \& Macías, V. D. F. (2015). A Call for Language Assessment Literacy in the Education and Development of Teachers of English as a Foreign Language. Colombian Applied Linguistics Journal, 17, 302-312. https://doi.org/10.14483/udistrital.jour.calj.2015.2.a09

Hill, S. (2010). Oral Language Play and Learning (Doctoral Dissertation). Australian Literacy Journal of Language \& Literacy, 33, 4-12.

Hung, Y. J. (2018). Group Peer Assessment of Oral English Performance in a Taiwanese Elementary School. Studies in Educational Evaluation, 59, 19-28. https://doi.org/10.1016/j.stueduc.2018.02.001

Iber, G. (2014). English Language Teaching in Malaysia: The Case for a Dual Track English Curriculum. Advances in Language and Literary Studies, 5, 68-71.

https://doi.org/10.7575/aiac.alls.v.5n.4p.68 
IELTS (2018). Test Taker Performance 2018.

IELTS (2019). Required IELTS Scores at UK Universities.

Jalaluddin, N. H., Norsimah, M. A., \& Kesumawati, A. B. (2008). The Mastery of English Language among Lower Secondary School Students in Malaysia: A Linguistic Analysis. European Journal of Social Sciences, 7, 106-119.

Kaur, N. (2006). Non-Autonomy and Low-English Proficiency among Malaysian Students: Insights from Multiple Perspectives. In K. Ariffin, M. Rozaidi Ismail, N. K. Leng, \& R. A. Aziz (Eds.), English in the Malaysian Context (pp. 21-34). Shah Alam: University Publication Centre (UPENA) UiTM.

Knapp, K., Seidlhofer, B., \& Widdowson, H. (2009). Introduction: Developing Foreign Language Communication: Principles and Practices. In Handbook of Foreign Language Communication and Learning (pp. 1-20). Berlin: De Gruyter. https://doi.org/10.1515/9783110214246.0.1

Lan, C., \& Fan, S. (2019). Developing Classroom-Based Language Assessment Literacy for In-Service EFL Teachers: The Gaps. Studies in Educational Evaluation, 61, 112-122. https://doi.org/10.1016/j.stueduc.2019.03.003

Le Ha, P., Kho, J., \& Chng, B. (2013). Nation Building, English as an International Language, Medium of Instruction, and Language Debate: Malaysia and Possible Ways Forward. Journal of International and Comparative Education (JICE), 2, 58-71. https://doi.org/10.14425/00.50.27

Luoma, S. (2004). Assessing Speaking. Cambridge: Cambridge University Press. https://doi.org/10.1017/CBO9780511733017

Ministry of Education Malaysia (2012). Malaysia Education Blueprint 2013-2025.

Mohd Uri, N. F., \& Abd Aziz, M. S. (2018). Implementation of CEFR in Malaysia: Teachers’ Awareness and the Challenges. 3L: Language, Linguistics, Literature ${ }^{\circledR}, 24,168-183$. https://doi.org/10.17576/3L-2018-2403-13

Musa, N. C., Lie, K. Y., \& Azman, H. (2012). Exploring English Language Learning and Teaching in Malaysia. GEMA Online ${ }^{\circledast}$ Journal of Language Studies, 12, 35-51.

Nunan, D. (2003). The Impact of English as a Global Language on Educational Policies and Practices in the Asia-Pacific Region. TESOL Quarterly, 37, 589-613. https://doi.org/10.2307/3588214

Paneerselvam, A., \& Mohamad, M. (2019). Learners' Challenges and English Educators' Approaches in Teaching Speaking Skills in an ESL Classroom: A Literature Review. Creative Education, 10, 3299-3305. https://doi.org/10.4236/ce.2019.1013253

Sidhu, G. K., Kaur, S., \& Chi, L. J. (2018). CEFR-Aligned School-Based Assessment in the Malaysian Primary ESL Classroom. Indonesian Journal of Applied Linguistics, 8, 452463. https://doi.org/10.17509/ijal.v8i2.13311

Stiggins, R. J. (1991). Assessment Literacy. Phi Delta Kappan, 72, 534-539.

Suah, S. L., \& Ong, S. L. (2012). Investigating Assessment Practices of In-Service Teachers. International Online Journal of Educational Sciences, 4, 91-106.

Vongpumivitch, V. (2012). English-as-a-Foreign-Language Assessment in Taiwan. Language Assessment Quarterly, 9, 1-10. https://doi.org/10.1080/15434303.2012.649592 